\title{
A new marsh plant community of Eleocharito palustris-Alismatetum lanceolati (Eleocharito palustris-Sagittarion sagittifoliae alliance) in Slovakia
}

\author{
Richard Hrivnák ${ }^{1 *}$, Michal Slezák ${ }^{1,2,3}$, Kateřina Šumberová4, Zdenka Hroudová ${ }^{5}$ \\ ${ }^{1}$ Institute of Botany, Slovak Academy of Sciences, Dúbravská cesta 9, 84523 Bratislava, Slovakia \\ ${ }^{2}$ Department of Biology and Ecology, Faculty of Education, Catholic University, Hrabovská cesta 1, 03401 Ružomberok, Slovakia \\ ${ }^{3}$ Department of Phytology, Faculty of Forestry, Technical University in Zvolen, T.G. Masaryka 24, 96053 Zvolen, Slovakia \\ ${ }^{4}$ Department of Vegetation Ecology, Institute of Botany, The Czech Academy of Sciences, Lidická 25/27, 60200 Brno, Czech Republic \\ ${ }^{5}$ Department of Genetic Ecology, Institute of Botany, The Czech Academy of Sciences, Zámek 1, 25243 Průhonice, Czech Republic
}

\begin{abstract}
Open and species-poor stands with a dominance of Alisma lanceolatum were recorded in periodically flooded habitats of the southern part of central Slovakia (Ipel' River catchment area) during the summer of 2013. Phytosociological relevés correspond to the association Eleocharito palustris-Alismatetum lanceolati (alliance Eleocharito palustris-Sagittarion sagittifoliae), which is reported and documented here for the first time from the territory of Slovakia. It inhabits predominantly temporarily flooded depressions on agricultural land - wet arable fields and extensively used pastures. Detrended correspondence analysis showed that the variability in species composition was most significantly influenced by water depth, the presence of arable fields in the contact area and water conductivity. Special attention was paid to a detailed description of the floristic composition, habitat requirements, distribution patterns and nomenclature of the community.
\end{abstract}

Keywords: Alisma lanceolatum; Central Europe; Eleocharito palustris-Sagittarion sagittifoliae; nomenclature; wetland vegetation

\section{Introduction}

Wetlands, namely habitats with a shallow and fluctuating water level, represent one of the most dynamic ecosystems in the Central-European landscape. Spatial and temporal changes in habitat conditions are important drivers of their community structure and species composition. Vegetation research of aquatic and marsh habitats can thus still offer new and relevant data, including the first recorded presence of plant communities within investigated areas. The same is also true for the freshwater amphibious herbaceous vegetation of periodically flooded habitats, which corresponds to the phytosociological alliance Eleocharito palustris-Sagittarion sagittifoliae (syn. Oenanthion aquaticae Hejný ex Neuhäusl 1959). For example, the association of Oenanthetum aquaticae was recently documented for the first time in Hungary [1], whereas the Batrachio circinati-Alismatetum graminei association has been known for the last few years in Slovakia [2]. A comprehensive taxonomic revision of the genus Bolboschoenus at a European scale [3] and new phytosociological

\footnotetext{
* Corresponding author. Email: richard.hrivnak@savba.sk
} Handling Editor: Zygmunt Dajdok data from flooded arable land enabled the description of the new association Tripleurospermo inodori-Bolboschoenetum planiculmis in Central Europe [4]. This community occurs most often on base-rich substrates in the Czech Republic, Slovakia, and at scattered localities in Poland, Germany, Austria and Hungary [4].

Stands of the alliance Eleocharito palustris-Sagittarion sagittifoliae are closely associated with intra- and inter-annual fluctuations in water level, i.e., from floods to shallow water and temporary drying out in the summer. They are less tolerant to long-term stable water tables, which support the growth of other types of marsh and aquatic vegetation [5-8]. In Slovakia, specific climatic conditions with a high precipitation during the spring period of 2013 promoted the development of periodic pools in shallow depressions across alluvial meadows and agricultural land (e.g., arable fields, pastures), which are considered to be favorable for vegetation of the alliance Eleocharito palustris-Sagittarion sagittifoliae [6].

Herbaceous vegetation types with dominance and/or higher cover of species Alisma lanceolatum With. have been relatively poorly documented in Central Europe. Although they have been recorded under different names, their syntaxonomical affiliation to the classes Phragmito-Magno-Caricetea 
or Isoëto-Nano-Juncetea is clear [1,7-9]. Only one record exists for an association with a dominance of A. lanceolatum in the Slovak phytosociological literature (Butomo-Alismatetum lanceolati) [10], but without any available relevés and therefore, subsequent studies did not adopt this association name (e.g., [6,11]). Vegetation with A. lanceolatum, observed in experimentally established paddy fields in the Slovak lowlands [12], most likely resulted in the inclusion of this association into the vegetation checklist published by Mucina and Maglocký [10].

The perennial herb Alisma lanceolatum, which can also behave as an annual species, is a relatively common component of the phytocoenoses of the alliance Eleocharito palustris-Sagittarion sagittifoliae in southern Slovakia, also including the catchment area of the Ipel' River [13]. Although intensive research of aquatic and marsh vegetation was conducted in this part of the Pannonian region [14-17], stands with a dominance of $A$. lanceolatum have not yet been found. We supposed that this plant community might appear periodically following fluctuations in the water regime of the habitat, as a consequence of the weather course in a given year.

The present study aimed to $(i)$ revise localities with the occurrence of Alisma lanceolatum in southern Slovakia and to sample vegetation with its dominance, and (ii) analyze their floristic composition and ecology.

\section{Material and methods}

Marsh vegetation containing the dominant species Alisma lanceolatum was sampled using the traditional ZürichMontpellier approach [18] in the catchment area of the Ipel' River (southern Slovakia; Fig. 1) in May and June, 2013. The cover of plant species was recorded with the extended nine-degree Braun-Blanquet cover/abundance sampling scale [19]. Twelve phytosociological relevés collected by the authors were stored with the help of TURBOVEG database software [20]. The following environmental variables (Tab. 1) were recorded at each sampling site: $(\boldsymbol{i})$ water-related variables such as depth, temperature, reaction and conductivity were measured using the EUTECH Instrument (CyberScan series 600); (ii) the type of contact habitat (arable fields, meadows, pastures) was visually estimated and used only for a description of the surroundings. Longitude, latitude and altitude were measured in the field using equipment Garmin GPSmap 62.

The TWINSPAN classification algorithm [21] with three pseudo-species cut levels ( $0 \%, 5 \%$ and $25 \%$ ), implemented in the JUICE program [22], was applied to identify and interpret variation in floristic composition. Major environmental gradients in species composition were analyzed by the unconstrained ordination technique in the CANOCO 4.5 package [23], as the length of the gradient in detrended correspondence analysis was 3.24 SD units. Detrended correspondence analysis (DCA) was performed with detrending by segments, square-root transformation of species cover values and without down-weighting of rare species. Environmental factors were plotted into a DCA ordination diagram as supplementary variables. Their values were correlated with the position of the releve scores in the first two DCA axes using Spearman's correlation coefficient. Differences between two distinguished vegetation variants for environmental variables were tested by the Mann-Whitney U test in STATISTICA software [24].

The nomenclature of plant species follows the checklist by Marhold and Hindák [25], except for the species Bolboschoenus laticarpus Marhold \& al., Eryngium pusillum L., Juncus fontanesii J. Gay ex Laharpe and Lythrum junceum Banks \& Sol. Names of aggregate taxa were used only in cases where the species could not be reliably determined. The names of plant communities were unified according to the Czech vegetation checklists [7,26], with the exception of Eleocharito palustris-Alismatetum lanceolati Minissale \& Spampinato 1985. A nomenclatural aspect of this association is extensively discussed in this study, following the rules of the International Code of Phytosociological Nomenclature (ICPN) [27]. In accordance with the Czech wetland vegetation checklist [7], we use following forms of the names for two of the classes mentioned in the text: Phragmito-MagnoCaricetea and Isoëto-Nano-Juncetea, i.e., with the separation of the prefixes "Magno" and "Nano" by a hyphen. The ICPN [27] enables the use of ecological and morphological prefixes before 1979 (see ICPN art. 12); however, the rule for the particular form (either with or without separation by a hyphen) is lacking. Therefore, to clarify the concept of the names with prefixes, Dengler et al. [28] recommended the separation by the hyphen.

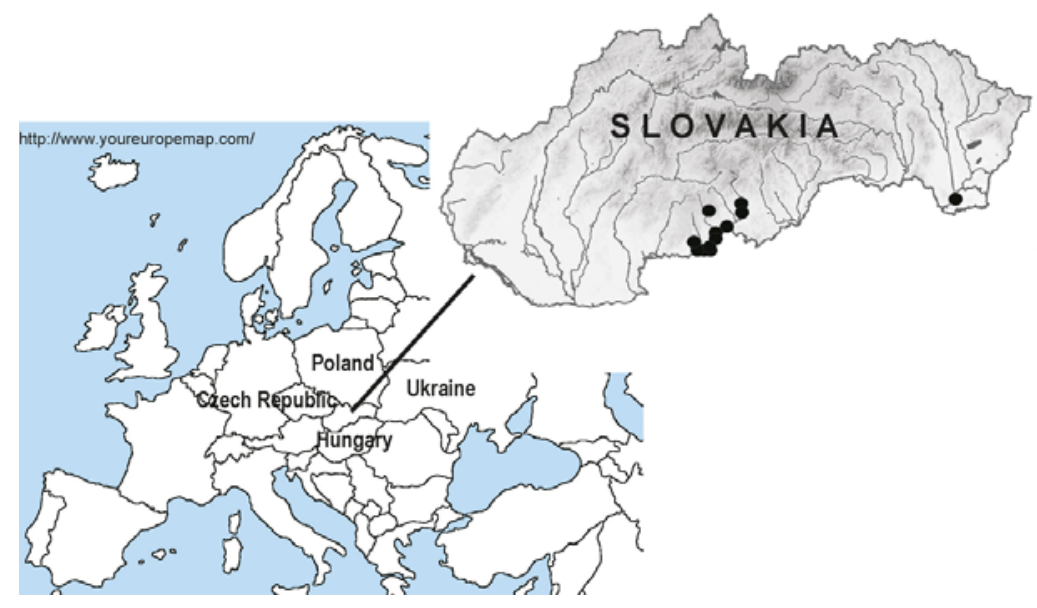

Fig. 1 Distribution map of Eleocharito palustris-Alismatetum lanceolati in Slovakia. 
Tab. 1 Basic statistics of environmental variables.

\begin{tabular}{|c|c|c|c|c|}
\hline \multirow[b]{2}{*}{ Relevé number } & \multicolumn{4}{|c|}{ Water } \\
\hline & Max depth (cm) & Temperature $\left({ }^{\circ} \mathrm{C}\right)$ & Reaction & Conductivity $(\mu \mathrm{S} / \mathrm{cm})$ \\
\hline 1 & 3 & 19.2 & 7.7 & 980 \\
\hline 2 & 0 & . & . & . \\
\hline 3 & 15 & 18.8 & 7.6 & 1215 \\
\hline 4 & 3 & 19.9 & 8.0 & 345 \\
\hline 5 & 2 & 17.0 & 7.8 & 1110 \\
\hline 6 & 6 & 20.3 & 7.8 & 700 \\
\hline 7 & 20 & 17.7 & 7.4 & 493 \\
\hline 8 & 20 & 23.3 & 6.9 & 153 \\
\hline 9 & 30 & 23.4 & 6.5 & 387 \\
\hline 10 & 2 & 24.1 & 6.9 & 1420 \\
\hline 11 & 20 & 17.2 & 7.5 & 739 \\
\hline 12 & 100 & 22.6 & 6.7 & 121 \\
\hline Mean $\pm S D$ & $18.4 \pm 27.5$ & $20.3 \pm 2.6$ & $7.3 \pm 0.5$ & $696.6 \pm 439.6$ \\
\hline Max & 100 & 24.1 & 8.0 & 1420 \\
\hline Min & 0 & 17.0 & 6.5 & 121 \\
\hline
\end{tabular}

\section{Results}

All recorded relevés with a dominance of Alisma lanceolatum represent open (mean herb layer cover 67\%) and species-poor (5-19 species per relevé) herbaceous vegetation (Tab. 2, Fig. 2). The herb layer usually contains plants of periodically flooded habitats (Bolboschoenus maritimus agg. - mainly B. laticarpus and B. maritimus s.s., Eleocharis palustris, Phellandrium aquaticum) and annual wetland herbs (Juncus bufonius agg., Lythrum hyssopifolia), which are accompanied by weeds and species that are adapted to wet disturbed habitats (e.g., Echinochloa crusgalli, Elytrigia repens). The floristic spectrum is enriched by several hygrophilous species with a broader ecological range (e.g., Juncus articulatus, Rorippa sylvestris), together with species of the class Bidentetea tripartitae (e.g., Alopecurus aequalis, Bidens tripartita and Ranunculus sceleratus). Overall species composition corresponds to the association Eleocharito palustris-Alismatetum lanceolati and to the alliance Eleocharito palustris-Sagittarion sagittifoliae (class Phragmito-Magno-Caricetea). We distinguished two floristic variants according to their variability in species composition (Tab. 2). The species-poorer variant (11 species per relevé) was distinguished especially by the presence of Bolboschoenus maritimus agg. and Elytrigia repens (relevés 1-5), whereas the species-richer variant (13 species per relevé) included a set of annual and perennial wetland plant taxa such as Alopecurus geniculatus, Juncus bufonius agg. and Lythrum hyssopifolia (relevés 6-12).

The association Eleocharito palustris-Alismatetum lanceolati was found along the Ipel' River and its tributaries (Fig. 1) at altitudes of 137-218 (438) m. It was found in field depressions with shallow water $(2-30 \mathrm{~cm})$ and fluctuating water levels or in permanent pools on agricultural land, including the wet parts of both arable fields and extensively used pastures. It can occasionally also occur in littoral zones of artificial water reservoirs, where the water table reaches ca. $1 \mathrm{~m}$. These small-scale stands $\left(<50 \mathrm{~m}^{2}\right)$ colonized clayey and muddy substrates, but they also tolerate sandy soils. A decline in the water level towards early summer and gradual overgrowth of the studied community by annual plants, weeds and more tolerant perennial species, which can occur for a few weeks, negatively affects the vitality and abundance of Alisma lanceolatum individuals.

Floristic variants significantly $(P<0.05)$ differed according to the water $\mathrm{pH}$, which showed a neutral to slightly basic reaction (Tab. 1). The DCA ordination showed a significant relationship between the first DCA axis and water depth $(r=0.76, P<0.01)$, the presence of arable fields in the contact area $(r=-0.71, P<0.05)$ and water conductivity $(r=-0.66$, $P<0.05$; Fig. 3 ).

In addition to the present data from the catchment area of the Ipel' River (Tab. 2), there is only one available phytosociological relevé of the association Eleocharito palustrisAlismatetum lanceolati in Slovakia. This was sampled in the Východoslovenská nížina Lowland (eastern Slovakia) and was stored in the Czech Phytosociological Database (ID number 448368; isolated dot in Fig. 1).

Relevé A. Východoslovenská nížina Lowland, Somotor, NW, river oxbow, area $16 \mathrm{~m}^{2}$, herb layer cover $\left(\mathrm{E}_{1}\right) 70 \%$, water depth $20 \mathrm{~cm}, 1.7 .1985$, author: Z. Hroudová.

$\mathrm{E}_{1}$ : Alisma lanceolatum 3, Eleocharis palustris 2, Agrostis stolonifera 1, Glyceria fluitans 1, Rorippa amphibia 1, Carex vulpina +, Glyceria maxima +, Gratiola officinalis + , Lycopus exaltatus + , Lythrum virgatum + , Persicaria amphibia + , Phellandrium aquaticum + , Sium latifolium + . 
Tab. 2 Phytosociological relevés of Eleocharito palustris-Alismatetum lanceolati.

\begin{tabular}{|c|c|c|c|c|c|c|c|c|c|c|c|c|c|c|c|c|}
\hline Relevé number & * & 1 & 2 & 3 & 4 & 5 & 6 & 7 & 8 & 9 & 10 & 11 & 12 & C & Cv1 & Cv2 \\
\hline \multicolumn{17}{|c|}{ Dominant species of association Eleocharito palustris-Alismatetum lanceolati } \\
\hline Alisma lanceolatum & $\mathrm{Pm}$ & 3 & 3 & 4 & 4 & 4 & 4 & 4 & 5 & 4 & 3 & 3 & 3 & 100 & 100 & 100 \\
\hline \multicolumn{17}{|l|}{ Diagnostic taxa of variants } \\
\hline Bolboschoenus maritimus agg. & $\mathrm{Pm}$ & ${ }^{\#} 2 \mathrm{a}$ & $s_{+}$ & + & 1 & . & . & . & . & . & . & . & . & 33 & 80 & 0 \\
\hline Elytrigia repens & & + & + & . & + & + & . & . & . & . & + & . & . & 42 & 80 & 14 \\
\hline Cirsium arvense & & . & + & . & 1 & + & . & . & . & . & . & . & . & 25 & 60 & 0 \\
\hline Juncus bufonius agg. & In & . & . & . & $\cdot$ & . & + & + & + & + & $2 \mathrm{a}$ & . & . & 42 & 0 & 71 \\
\hline Lythrum hyssopifolia & In & . & . & . & . & . & + & + & 1 & + & 3 & . & . & 42 & 0 & 71 \\
\hline Alopecurus geniculatus & $\mathrm{Ma}$ & . & . & . & . & . & $2 b$ & 1 & 1 & . & . & 1 & . & 33 & 0 & 57 \\
\hline Lemna minor & Le & . & . & . & $\cdot$ & . & + & . & . & . & . & + & 3 & 25 & 0 & 43 \\
\hline Bidens tripartita & $\mathrm{Bi}$ & . & . & . & . & . & $\cdot$ & + & + & . & + & . & . & 25 & 0 & 43 \\
\hline Glyceria fluitans & $\mathrm{Pm}$ & . & . & . & . & . & . & . & 1 & + & . & . & 1 & 25 & 0 & 43 \\
\hline Rorippa sylvestris & & . & . & . & . & . &. & . & + & . & + & 1 & & 25 & 0 & 43 \\
\hline
\end{tabular}

Other species with occurrence at least in two relevés

\begin{tabular}{|c|c|c|c|c|c|c|c|c|c|c|c|c|c|c|c|c|}
\hline Echinochloa crus-galli & & . & . & . & + & + & $2 \mathrm{~b}$ & + & + & + & 1 & . & . & 58 & 40 & 71 \\
\hline Ranunculus sceleratus & $\mathrm{Pm}, \mathrm{Bi}$ & . & . & 1 & + & . & . & $\mathrm{r}$ & . & 1 & + & 1 & . & 50 & 40 & 57 \\
\hline Veronica anagallis-aquatica & $\mathrm{Pm}$ & . & $2 \mathrm{a}$ & 1 & . & . & $\mathrm{r}$ & $\cdot$ & . & . & + & . & . & 33 & 40 & 29 \\
\hline Phellandrium aquaticum & $\mathrm{Pm}$ & . & + & . & . & . & . & $\cdot$ & + & + & . & $\mathrm{r}$ & . & 33 & 20 & 43 \\
\hline Eleocharis palustris & $\mathrm{Pm}$ & . & . & . & . & + & . & + & . & $2 \mathrm{a}$ & . & 1 & . & 33 & 20 & 43 \\
\hline Limosella aquatica & In & + & + & . & . & & . & $\cdot$ & . & + & . & . & . & 25 & 40 & 14 \\
\hline Ranunculus sardous & In & . & + & . & . & + & . & . & . & . & $2 \mathrm{a}$ & . & . & 25 & 40 & 14 \\
\hline Lythrum virgatum & $\mathrm{Ma}$ & . & . & . & . & + & . & + & . & + & . & . & . & 25 & 20 & 29 \\
\hline Persicaria amphibia & & $2 \mathrm{a}$ & . & . & . & & . & . & . & . & . & + & . & 17 & 20 & 14 \\
\hline Ambrosia artemisiifolia & & + & $\mathrm{r}$ & . & . & & . & $\cdot$ & . & . & . & . & . & 17 & 40 & 0 \\
\hline Elatine alsinastrum & In & + & . & . & . & $2 \mathrm{a}$ & . & . & . & . & . & . & . & 17 & 40 & 0 \\
\hline Alopecurus aequalis & $\mathrm{Bi}$ & + & . & . & . & & . & . & . & . & $2 \mathrm{a}$ & . & . & 17 & 20 & 14 \\
\hline Butomus umbellatus & $\mathrm{Pm}$ & . & $2 \mathrm{a}$ & . & . & & 1 & $\cdot$ & . & . & . & . & . & 17 & 20 & 14 \\
\hline Mentha aquatica & $\mathrm{Pm}$ & . & + & . & . & 1 & . & . & . & . & . & . & . & 17 & 40 & 0 \\
\hline Typha latifolia & $\mathrm{Pm}$ & . & . & . & . & + & . & . & . & + & . & . & . & 17 & 20 & 14 \\
\hline Juncus articulatus & & . & . & . & . & + & . & $\cdot$ & . & . & + & . & . & 17 & 20 & 14 \\
\hline Tripleurospermum inodorum & & . & . & . & . & & $\mathrm{r}$ & $\mathrm{r}$ & . & . & . & . & . & 17 & 0 & 29 \\
\hline Persicaria lapathifolia & $\mathrm{Bi}$ & . & . & . & . & & . & + & . & . & + & . & . & 17 & 0 & 29 \\
\hline Peplis portula & In & . & . & . & . & . & . & $\cdot$ & + & + & . & . & . & 17 & 0 & 29 \\
\hline Lycopus europaeus & $\mathrm{Pm}$ & . & . & . & . & . & . & $\cdot$ & . & + & + & . & . & 17 & 0 & 29 \\
\hline Sparganium erectum & $\mathrm{Pm}$ & . & . & . & . & . & . & . & . & + & . & + & . & 17 & 0 & 29 \\
\hline Rumex crispus & $\mathrm{Ma}$ & . & . & . & . & . & . & . & . & . & + & + & . & 17 & 0 & 29 \\
\hline
\end{tabular}

Legend: C - constancy; Cv1, Cv2 - constancy of the variants; * - syntaxon: Bi - Bidentetea tripartitae; In - Isoëto-Nano-Juncetea; Le Lemnetea; Ma - Molinio-Arrhenatheretea; Pm - Phragmito-Magno-Caricetea; ${ }^{*}$ Bolboschoenus laticarpus, ${ }^{\$}$ B. maritimus s.s. Species with occurrence only in one relevé: Agrostis stolonifera (2: +), Alopecurus pratensis (7: +), Bidens frondosa (9: r), Bromus inermis (10: r), Callitriche sp. (8: 1), Calystegia sepium (9: r), Carex hirta (7: +), Chara sp. (3: +), Equisetum palustre (3: 1), Gnaphalium uliginosum (5: +), Lycopus exaltatus (2: +), Lysimachia nummularia (12: 2a), Lythrum salicaria (9: +), Persicaria hydropiper (10: +), P. maculosa (11: +), Potentilla reptans (10:+), Ranunculus repens (6: +), Rorippa austriaca (9: +), Rumex palustris (8: +), Schoenoplectus lacustris (4: 1), Sch. supinus (1: r), Spirodela polyrhiza (12: +), Symphytum officinale (2: 1), Polygonum aviculare agg. (1: +), Trifolium hybridum (10: +), Xanthium albinum $(1:+)$. Localities of relevés: locality; longitude, latitude; altitude $(\mathrm{m})$; area $\left(\mathrm{m}^{2}\right)$; aspect $\left({ }^{\circ}\right)$; slope $\left(^{\circ}\right)$; cover $\mathrm{E}_{1}(\%)$; date; authors. 1 - Kováčovce village, SSW; 19²7'30.6", 4805'18.1"; 151; 11; 60; 1; 55; 2013.06.11; Hrivnák, Slezák. 2 - Vrbovka village, E; 19²5’07.3", 4805'34.7"; 156; 15; 0; 0; 60; 2013.06.11; Hrivnák, Slezák. 3 - Želovce village, NNW; 19²2'50.8", 4807'58.9"; 156; 15; 0; 0; 60; 2013.05.30; Hrivnák, Slezák. 4 - Seleštany village, NW; 19¹9'14.2", 4806'23.2"; 145; 15; 0; 0; 70; 2013.05.30; Hrivnák, Slezák. 5 - Kováčovce village, E; 19²7'36.4", 4805'29.7"; 151; 15; 0; 0; 60; 2013.06.11; Hrivnák, Slezák. 6 - Trenč village, Hámor settlement, E; 19³1'40.6", 48¹2'47.5"; 165; 16; 0; 0; 70; 2013.05.30; Hrivnák, Slezák. 7 - Bušince village, NE; 19³0'15.8", 48º'10'57.4"; 162; 15; 0; 0; 75; 2013.05.30; Hrivnák, Slezák. 8 - Zelené village, WSW; $19^{\circ} 46^{\prime} 01.2^{\prime \prime}, 48^{\circ} 25^{\prime} 38.6^{\prime \prime} ; 218 ; 16 ; 0 ; 0 ; 85 ; 2013.06 .12$; Hrivnák, Slezák. 9 - Velké Dálovce village, SSE; 19³6'39.3", 48¹5'10.9"; 172; 15; 0; 0; 70; 2013.06.11; Hrivnák, Slezák. 10 - Pinciná village, W; 1944'57.2", 48²1'29.6"; 195; 7.5; 0; 0; 80; 2013.06.15; Hrivnák. 11 - Ipel'ské Predmostie village, W; 1903'03.6", 4803'56.0"; 137; 15; 0; 0; 50; 2013.05.30; Hrivnák, Slezák. 12 - Velký Lom village, $\mathrm{N} ; 19^{\circ} 22^{\prime} 11.4^{\prime \prime}, 48^{\circ} 20^{\prime} 39.4^{\prime \prime} ; 438 ; 12 ; 0 ; 0 ; 60 ; 2013.06 .24$; Hrivnák, Kochjarová, Otahelová. 

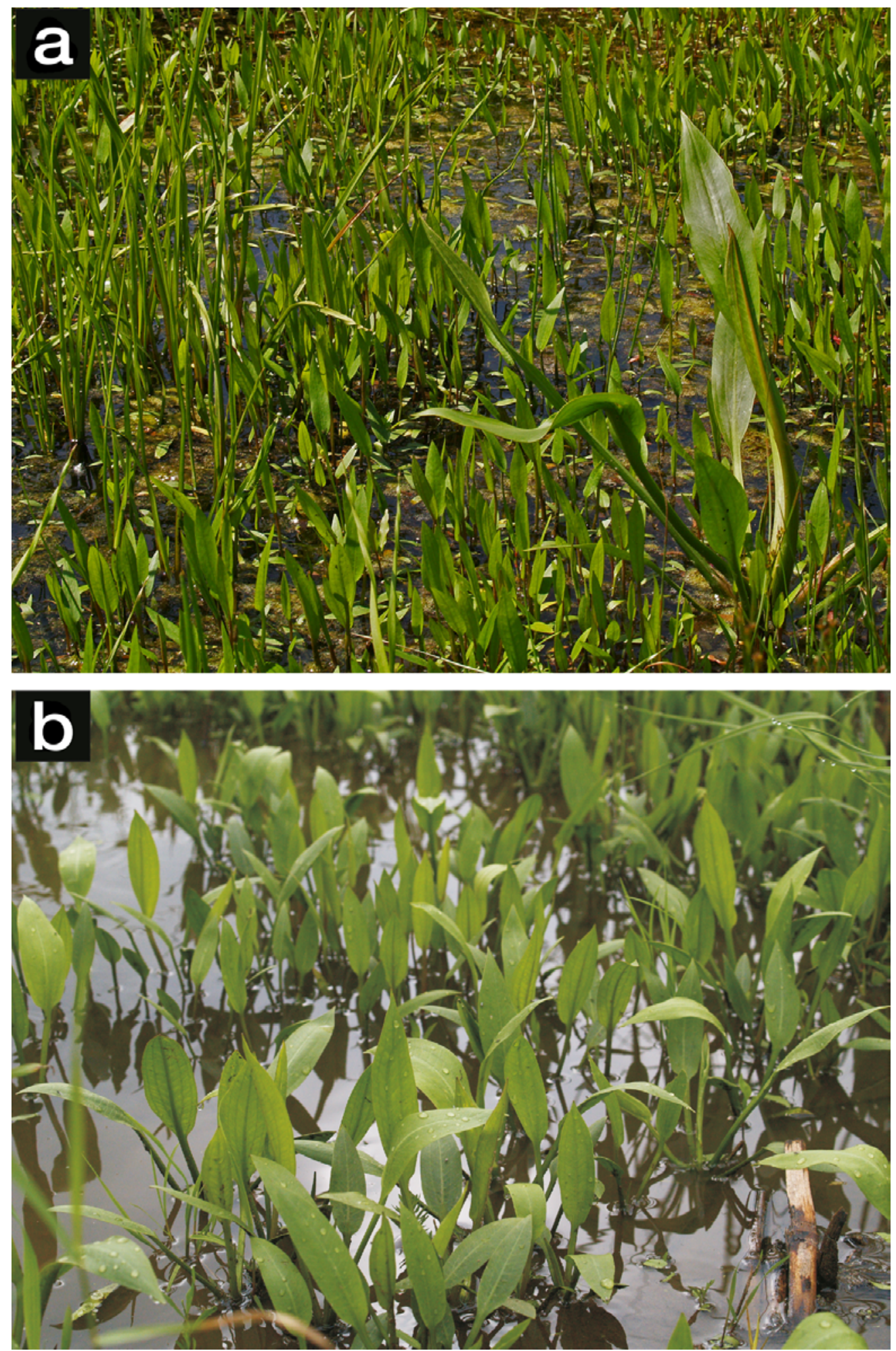

Fig. 2 Vegetation of Eleocharito palustris-Alismatetum lanceolati in the Ipel' River catchment area, Ipel'ské Predmostie (a) and Kováčovce (b).

\section{Discussion}

The first record of the association Eleocharito palustrisAlismatetum lanceolati in Slovakia confirmed our assumption concerning its occurrence in the Pannonian region, as Alisma lanceolatum may encounter suitable conditions there for its potential establishment, successful growth and spread into a broad range of wetland habitats. Several aquatic and marsh plant communities with the presence of A. lanceolatum have been already recorded in this floristically distinctive part of Central Europe (e.g., [6-8,13]), but Eleocharito palustrisAlismatetum lanceolati was overlooked in Slovakia for several years. These fragmentary and usually small-scale stands were found in habitats in regions with a relatively warm climate, 


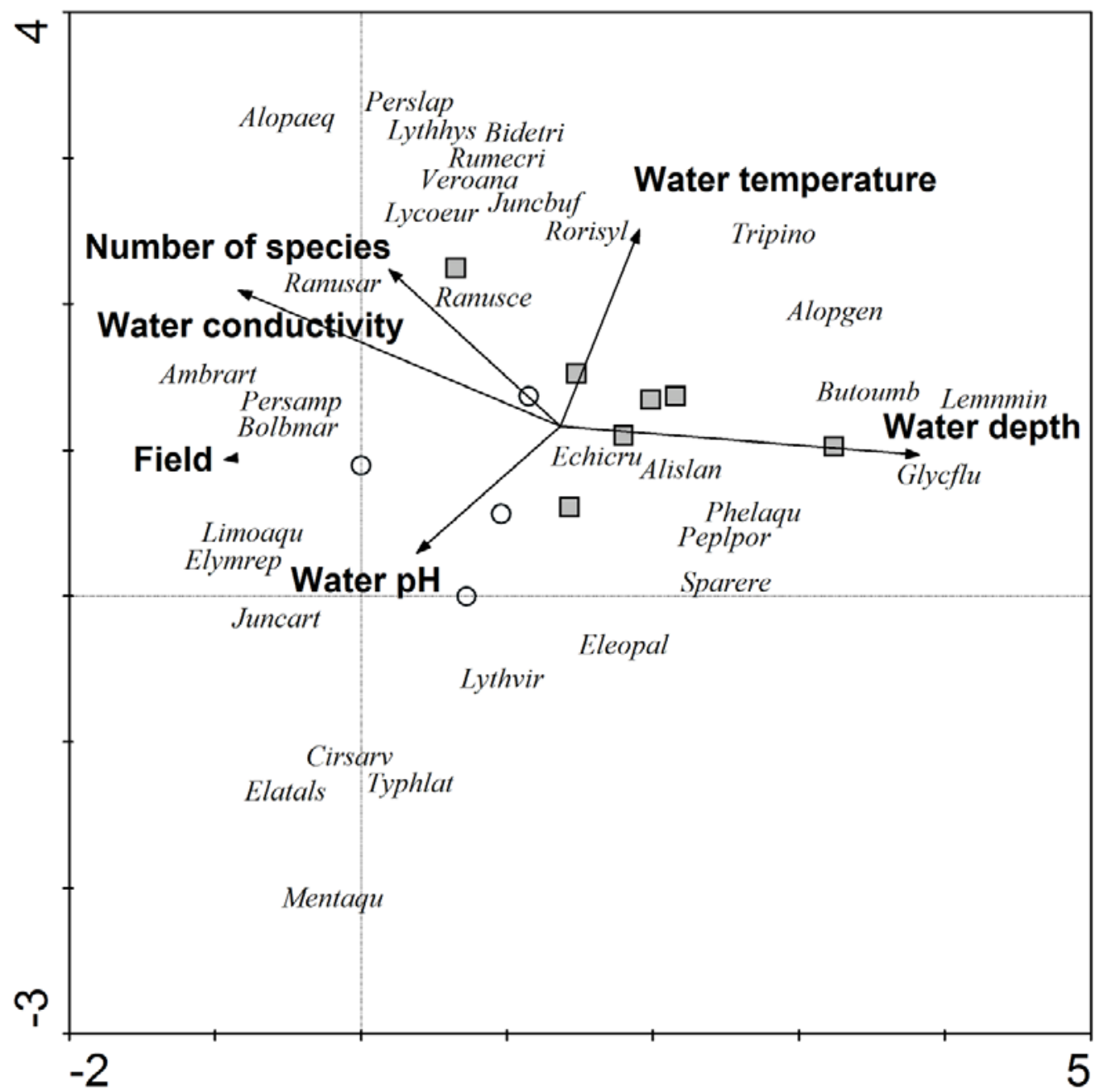

Fig. 3 DCA ordination diagram with species, samples (circles - species-poorer variant, Tab. 2, relevés 1-5; squares - species-richer variant, Tab. 2, relevés 6-12) and explanatory variables for Eleocharito palustrisAlismatetum lanceolati in Slovakia. The first two DCA axes explain $27.6 \%$ and $28.2 \%$ of the species data variability and species-environment relationship, respectively. Only species occurring in at least two relevés are shown (Alislan - Alisma lanceolatum, Alopaeq - Alopecurus aequalis, Alopgen - Alopecurus geniculatus, Ambrart - Ambrosia artemisiifolia, Bidetri - Bidens tripartita, Bolbmar - Bolboschoenus maritimus agg., Butoumb - Butomus umbellatus, Cirsarv - Cirsium arvense, Echicr - Echinochloa crus-galli, Elatals - Elatine alsinastrum, Eleopal - Eleocharis palustris, Elymrep - Elytrigia repens, Glycflu - Glyceria fluitans, Juncart Juncus articulatus, Juncbuf - Juncus bufonius agg., Lemnmin - Lemna minor, Limoaqu - Limosella aquatica, Lycoeur - Lycopus europaeus, Lythhys - Lythrum hyssopifolia, Lythvir - Lythrum virgatum, Peplpor - Peplis portula, Persamp - Persicaria amphibia, Perslap - Persicaria lapathifolia, Phelaqu - Phellandrium aquaticum, Ranusar - Ranunculus sardous, Ranusce - Ranunculus sceleratus, Rorisyl - Rorippa sylvestris, Rumecri - Rumex crispus, Sparere - Sparganium erectum, Tripino - Tripleurospermum inodorum, Typhlat - Typha latifolia, Veroana - Veronica anagallis-aquatica).

which showed environmental properties similar to those in other Central European countries such as Hungary and the Czech Republic. These stands prefer wet field depressions in agricultural land with shallow stagnant water with a neutral to slightly basic reaction. This vegetation type grows on clayey and muddy substrates, generally under the absence of organic sediment (see also [7,8]). If available knowledge about the biology, ecology and distribution of A. lanceolatum are taken into account, Eleocharito palustris-Alismatetum lanceolati is also expected to be present in other parts of southern Slovakia.
The association was originally described by Minissale and Spampinato [29] from northwestern Sicily (Italy) as Eleocharido-Alismetum lanceolati. We have added the species epithet (ICPN recomm. 10C) and interpreted the name in the form Eleocharito palustris-Alismatetum lanceolati, as the phytosociological material in the association's protologue consisted only of the species Eleocharis palustris. This association was introduced to the international audience in a contemporary overview of the class Phragmito-MagnoCaricetea for central Italy [30]. We have found a high floristic similarity between Italian [29] and Slovak phytosociological 
relevés (Tab. 2). The phytosociological material of the original diagnosis [29] contains only a few species that are lacking in the Central European flora (e.g., Eryngium pusillum, Juncus fontanesii, Lythrum junceum), but these are not assigned as the diagnostic ones for Eleocharito palustris-Alismatetum lanceolati and have only low cover values. These species are typical for wetlands, e.g., wet grasslands, fens or temporary pools $[31,32]$. They may enter into the community from contact vegetation or develop from soil seed banks in early summer when the water level drops down. On the contrary, an abundant set of species with vegetation affinity to the alliance Eleocharito palustris-Sagittarion sagittifoliae (e.g., Alisma lanceolatum, Bolboschoenus maritimus agg., Butomus umbellatus, Eleocharis palustris; Tab. 2), supports the assignment of Slovak stands into the association Eleocharito palustris-Alismatetum lanceolati. The floristic structure of the herb layer is further enriched by species with an optimum in eutrophic wetlands (Alopecurus aequalis, Typha latifolia), but conditions are also suitable for annual plants from habitats where water levels decrease to the bottom (Juncus bufonius agg., Limosella aquatica, Lythrum hyssopifolia). The relationship between vegetation and arable land can be found in the higher frequency of moisture-demanding or flood-tolerant ruderal species and weeds such as Cirsium arvense, Echinochloa crus-galli and Elytrigia repens. The coexistence of different plant functional groups in the Eleocharito palustris-Alismatetum lanceolati association has already been demonstrated in several other European countries [7,30,33].

Most Central- and Eastern-European scientific sources commonly used another two older, but invalidly published names for the stands of Alisma lanceolatum (e.g., [8,34-38]). The first name, Butomo-Alismatetum lanceolati, is usually accompanied by the erroneous authorship "(Tímár 1957) Segal et Westhoff in Westhoff et den Held 1969”. Although Timár [39] proposed the assignment of vegetation with a high cover of Alisma lanceolatum to the community Bolboschoenetum maritimi and distinguished type with A. lanceolatum, Segal \& Westhoff (cited in [40]) did not refer to Tímár's description and distinguished Butomo-Alismatetum lanceolati as a new association. The original diagnosis did not contain phytosociological relevés or a table [40], and therefore it must be regarded as an invalid description according to the ICPN (nomen nudum; art. 2b). In addition, A. lanceolatum was considered to be a characteristic species of this association [40], which resulted in a different syntaxonomical interpretation of the name Butomo-Alismatetum lanceolati (e.g., $[8,41])$. Several authors also ascribed vegetation with a dominance of Butomus umbellatus and the absence or negligible abundance of $A$. lanceolatum to this unit (e.g., $[37,42])$. Systematic research of wetlands in Central Europe (including the Carpathian-Pannonian region) continuously disentangles the habitat requirements of both name-giving species, especially their ecological behavior along a moisture gradient. While B. umbellatus prefers wetlands with deeper water, including slowly running waters and at least waterlogged soils, A. lanceolatum is much more frequent on sites where the water level periodically decreases and the upper parts of bottom substrate may even temporarily dry up (see also Fig. 3). When both species occur together in the same site, one of them usually prevails and the second species reaches only a low abundance. Our field observations agree with those from scarce relevés published in the literature $[33,38]$. Based on this coexistence pattern, we propose to classify the reed beds with diverse dominant species into different associations. The second association, Alismatetum lanceolati, was described by Zahlheimer [33] from Germany. Similar to the previous name, this name should be considered invalid (ICPN art. 5), because the author did not designate the nomenclatural type relevé (holotype; ICPN art. 19). It was validated subsequently by Šumberová (cited in [7]), who designated a lectotype from relevés published in the original diagnosis [33]. The correct form of the name is Alismatetum lanceolati Zahlheimer 1979 ex Šumberová in Chytrý [7] and it represents the syntaxonomic synonym of the Eleocharito palustris-Alismatetum lanceolati association.

Our detailed literature review suggests the absence of vegetation that is predominated or co-dominated by Alisma lanceolatum in most European countries. However, at least in some cases, the lack of data rather than the real absence of this vegetation type underlies the distribution gaps. Smallscale stands with specific micro-climatic requirements are most likely overlooked due to the short period in which the dominant species is fully developed and identifiable. Additionally, A. lanceolatum exhibits a much lower competitive ability than many common reed-bed species. Therefore, new findings of this association can be expected, particularly in regions with an evident regular drought period in summer that effectively suppresses the development of strong wetland competitors. In contrast, a warm and relatively humid climate overrides the effect of water shortage and promotes the growth of other vegetation types. These conditions allow Alisma lanceolatum to grow only as a part of the other marsh (Phragmito-Magno-Caricetea), aquatic (Lemnetea, Potametea, Charetea) or annual vegetation of exposed pond bottoms (in particular, of Bidentetea tripartitae). This pattern was identified, for instance in Poland, where A. lanceolatum is a widely distributed species [43]. The Polish Vegetation Database contains more than 2000 phytosociological relevés of the class Phragmito-Magno-Caricetea [44], but none of them can be assigned to the association Eleocharito palustris-Alismatetum lanceolati. Alisma lanceolatum reaches only negligible cover values (+ or 1) and such relevés are mostly classified into the classes Bidentetea tripartitae (e.g., [45]), Charetea or Potametea (e.g., [46]). In Hungary, Nagy et al. [1,9] described the association Alismato lanceolati-Veronicetum anagalloidis (Isoëto-Nano-Juncetea) from a floodplain in Bodrogköz (north-eastern edge of the Pannonian Basin). Typically developed stands are dominated by Veronica anagalloides, whereas A. lanceolatum shows only a low cover. Unlike the higher frequency of facultative halophytes and plants that mainly prefer disturbed sites $[1,8,9]$, species of the alliance Eleocharito palustris-Sagittarion sagittifoliae are less abundant in this vegetation type. The development of vegetation of the association Eleocharito palustris-Alismatetum lanceolati is not excluded, even in regions with a rather rare occurrence of, and sub-optimal conditions for, A. lanceolatum. Relatively suitable conditions are likely to occur there especially in habitats that are under distinctive management, including wetland grazing or the occasional ploughing of wetlands on arable land [47]. 


\section{Acknowledgments}

We would like to thank H. Otahelová and J. Kochjarová for their help in the field and Zygmunt Kącki for information about the occurrence of Alisma lanceolatum in Poland, including the relevés from the Polish Vegetation Database. This study was supported by the Slovak Research and Development Agency under the contract No. APVV-0059-11 (RH), by the Czech Science Foundation (Centre of Excellence PLADIAS, 14-36079G; ZH, KŠ) and by the Institute of Botany of the Czech Academy of Sciences (RVO 67985939; ZH, KŠ).

\section{Authors' contributions}

The following declarations about authors' contributions to the research have been made: field work, data analyses and manuscript preparation: $\mathrm{RH}, \mathrm{MS}$; manuscript preparation: KŠ, ZH.

\section{Competing interests}

No competing interests have been declared.

\section{References}

1. Nagy J, Gál B, Tuba Z, Szerdahelyi T, Czóbel S, Szirmai O, et al. Monodominant plant associations in the Bodrogköz (NE Hungary) new for science and for Hungary. Thaiszia. 2009;19(1 suppl):299-314.

2. Hrivnák R, Kochjarová J, Otahelová H. Vegetation of the aquatic and marshland habitats in the Orava region, including the first records of Potametum alpini, Potametum zizii and Ranunculo-Juncetum bulbosi in the territory of Slovakia. Biologia. 2011;66:626-637. http://dx.doi. org/10.2478/s11756-011-0060-Z

3. Hroudová Z, Zákravský P, Ducháček M, Marhold K. Taxonomy, distribution and ecology of Bolboschoenus in Europe. Ann Bot Fenn. 2007;44:81-102.

4. Hroudová Z, Hrivnák R, Chytrý M. Classification of inland Bolboschoenus-dominated vegetation in Central Europe. Phytocoenologia. 2009;39:205-215. http://dx.doi. org/10.1127/0340-269X/2009/0039-0205

5. Balátová-Tuláčková E, Mucina L, Ellmauer T, Wallnöfer S. PhragmitoMagnocaricetea. In: Grabherr G, Mucina L, editors. Die Pflanzengesellschaften Östrerreichs. Teil II. Natürliche waldfreie Vegetation. Jena: Gustav Fischer Verlag; 1993. p. 79-165.

6. Otahelová H, Hrivnák R, Valachovič M. Phragmito-Magnocaricetea. In: Valachovič M, editor. Rastlinné spoločenstvá Slovenska 3. Vegetácia mokradí. Bratislava: Veda; 2001. p. 51-183.

7. Chytrý M, editor. Vegetace České republiky 3. Vodní a mokřadní vegetace. Praha: Academia; 2011.

8. Borhidi A, Kevey B, Lendvai G. Plant communities of Hungary. Budapest: Akadémiai Kiadó; 2012.

9. Nagy J, Tuba Z, Szirmai O, Czóbel S, Gál B, Cserhalmi D, et al. A tudományra és hazánkra nézve új növénytársulásók a Bodrogközböl. In: Tuba Z, editor. Bodrogköz: Gödöllő-Sárospatak; 2008. p. 585-600.

10. Mucina L, Maglocký Š, editors. A list of vegetation units of Slovakia. Doc Phytosociol. 1985;9:175-220.

11. Jarolímek I, Šibík J, editors. Diagnostic, constant and dominant species of the higher vegetation units of Slovakia. Bratislava: Veda; 2008.

12. Hejný S. Ökologische Charakteristik der Wasser- und Sumpfpflanzen in den slowakischen Tiefebenen (Donau- und Theissgebieten). Bratislava: SAV; 1960.

13. Hrivnák R. Spoločenstvá zväzu Oenanthion aquaticae v povodí rieky Ipel. Bull Slov Bot Spoločn. 2003;25:169-183.

14. Hrivnák R. Aquatic plant communities in the catchment area of the Ipel' River in Slovakia and Hungary. Part I. Classes Lemnetea and Charetea fragilis. Thaiszia. 2002;12:25-50.

15. Hrivnák R. Aquatic plant communities in the catchment area of the Ipel' River in Slovakia and Hungary. Part II. Class Potametea. Thaiszia. 2002;12:137-160.

16. Hrivnák R. The plant communities of Phragmitetalia in the catchment area of the Ipel' River (Slovakia and Hungary) 1. Reed wetlands (Phragmition communis). Biologia. 2004;59:75-99.
17. Hrivnák R. The plant communities of Phragmitetalia in the catchment area of the Ipel' River (Slovakia and Hungary) 2. Tall-sedge dominated wetlands (Magnocaricion eletae). Biologia. 2004;59:457-476.

18. Westhoff V, van der Maarel E. The Braun-Blanquet approach. In: Whittaker RH, editor. Ordination and classification of communities. The Hague: Junk; 1973. p. 617-727.

19. Barkman JJ, Doing H, Segal S. Kritische Bemerkungen und Vorschläge zur quantitativen Vegetationsanalyse. Acta Bot Neerl. 1964;13:394-419. http://dx.doi.org/10.1111/j.1438-8677.1964.tb00164.x

20. Hennekens SM, Schaminée JHJ. TURBOVEG, a comprehensive data base management system for vegetation data. J Veg Sci. 2001;12:589_ 591. http://dx.doi.org/10.2307/3237010

21. Hill MO. TWINSPAN. A Fortran program for arranging multivariate data in an ordered two-way table by classification of the individuals and attributes. Ithaca, NY: Cornell University; 1979.

22. Tichý L. JUICE, software for vegetation classification. J Veg Sci. 2002;13:451-453. http://dx.doi.org/10.1111/j.1654-1103.2002. tb02069.x

23. ter Braak CJF, Šmilauer P. CANOCO Reference manual and CanoDraw for Windows User's guide. Software for Canonical Community Ordination (version 4.5). Ithaca, NY: Microcomputer Power; 2002.

24. StatSoft. STATISTICA. System reference. Tulsa, OK: StatSoft Inc.; 2001.

25. Marhold K, Hindák F, editors. Checklist of non-vascular and vascular plants of Slovakia. Bratislava: Veda; 1998.

26. Chytrý M, editor. Vegetace České republiky 1 . Travinná a keříčková vegetace. Praha: Academia; 2007.

27. Weber HE, Moravec J, Theurillat JP. International Code of Phytosociological Nomenclature. 3rd ed. J Veg Sci. 2000;11:739-768. http:// dx.doi.org/10.2307/3236580

28. Dengler J, Berg C, Eisenberg M, Isermann M, Jansen F, Koska I, et al. New descriptions and typifications of syntaxa within the project "Plant communities of Mecklenburg-Vorpommern and their vulnerability” - part I. Feddes Repert. 2003;114:587-631. http://dx.doi. org/10.1002/fedr.200311017

29. Minissale P, Spampinato G. Osservazioni fitosoziologiche sul "Lago Gurrida” (Sicilia Nord-Orientale). Giorn Bot Ital. 1985;119:197-225. http://dx.doi.org/10.1080/11263508509428015

30. Landucci F, Gigante D, Venanzoni R, Chytrý M. Wetland vegetation of the class Phragmito-Magno-Caricetea in central Italy. Phytocoenologia. 2013;43:67-100. http://dx.doi.org/10.1127/0340-269X/2013/0043-0545

31. Daoud-Bouattour A, Muller SD, Ferchichi-Ben Jamaa H, Ben Saad-Limam S, Rhazi L, Soulié-Märsche I, et al. Conservation of Mediterranean wetlands: interest of historical approach. C R Biol. 2011;334:742-756. http://dx.doi.org/10.1016/j.crvi.2011.07.006

32. Tutin TG, Heywood VH, Burges NA, Moore DM, Valentine DH, Walters SM, et al., editors. Flora Europaea. Vol. 5: Alismataceae to Orchidaceae. Cambridge: Cambridge University Press; 1980.

33. Zahlheimer WA. Vegetationsstudien in den Donauauen zwischen Regensburg und Straubing als Grundlage für den Naturschutz. Hoppea. 1979;38:3-398.

34. Moravec J, Balátová-Tuláčková E, Blažková D, Hadač E, Hejný S, Husák Š, et al. Rostlinná společenstva České republiky a jejich ohrožení. 2nd ed. Litoměřice: Okresní vlastivědné muzeum v Litoměřicích; 1995. (Severočeskou přírodou Př́loha; vol 3,1).

35. Schubert R, Herdam H, Weinitschke H, Frank J. Prodromus der Pflanzengesellschaften Sachsen-Anhalts. Mitt Florist Kart SachsenAnhalt. 2001;2(suppl):1-688.

36. Schubert R, Hilbig W, Klotz S. Bestimmungsbuch der Pflanzengesellschaften Deutschlands. Heidelberg: Spektrum Akademischer Verlag; 2001.

37. Chifu T, Mânzu C, Zamfirescu O. Flora şi vegetația Moldovei (România). II. Vegetația. Iaşi: Editura Universității, Alexandru Ioan Cuza; 2006.

38. Dubyna DV. Višča vodna roslynnist'. Kyïv: Instytut botaniky im. M.G. Kholodnogo NAN Ukraïny; 2006. 
39. Timár L. Zönologische Untersuchungen in den Äckern Ungarns. Acta Bot Acad Sci Hung. 1957;3:79-108.

40. Westhoff V, den Held AJ. Plantengemeenschappen in Nederland. Zutphen: Thieme; 1969.

41. Hejný S, Husák Š. Higher plant communities. In: Dykyjová D, Květ J, editors. Pond littoral ecosystems. Berlin: Springer-Verlag; 1978. p. 23-64. (Ecological Studies; vol 28). http://dx.doi. org/10.1007/978-3-642-66838-8_3

42. Drăgulescu C. Study of Phragmitetalia order vegetation in the range of Sibiu county (Transylvania, Romania). Rom J Aquat Ecol. 2011;1:19-44

43. Wayda M. Distribution of Alisma lanceolatum (Alismataceae) in Poland. Fragm Flor Geobot. 1997;42:43-48.
44. Kącki Z, Śliviński M. The Polish Vegetation Database: structure, resources and development. Acta Soc Bot Pol. 2012;81(2):75-79. http://dx.doi.org/10.5586/asbp.2012.014

45. Borysiak J. Struktura aluwialnej roślinności lądowej środkowego i dolnego biegu Warty. Poznań: Wydawnictwo Naukowe UAM; 1994.

46. Gąbka M, Dolata PT. Rzadkie i zagrożone zbiorowiska hydrofitów stawów rybnych południowej Wielkopolski. Badania Fizjograficzne. Seria B - Botanica. 2010;59:75-96.

47. Němec R, Dřevojan P, Šumberová K. Polní mokřady Znojemska jako refugium významných a vzácných druhů cévnatých rostlin. Thayensia. 2014;11:3-76. 